Article

\title{
Corruption Risks in Renewable Resource Governance: Case Studies in Iceland and Romania
}

\author{
Johanna Gisladottir ${ }^{1,3, *}$, Sigurbjörg Sigurgeirsdottir ${ }^{1}$, Ingrid Stjernquist ${ }^{2}$ and Kristin Vala Ragnarsdottir ${ }^{3}$ \\ ${ }^{1}$ Faculty of Political Science, University of Iceland, 102 Reykjavik, Iceland; E-Mails: jog31@hi.is (J.G.), silla@hi.is (S.S.) \\ 2 Department of Physical Geography, Stockholm University, 10691 Stockholm, Sweden; \\ E-Mail: ingrid.stjernquist@natgeo.su.se \\ ${ }^{3}$ Institute of Earth Science, University of Iceland, 102 Reykjavik, Iceland; E-Mail: vala@hi.is \\ * Corresponding author
}

Submitted: 14 December 2019 | Accepted: 17 March 2020 | Published: 28 May 2020

\begin{abstract}
In this research, we attempt to shed light on the question of where corruption risks in the governance of renewable resources are located and how they have been addressed in European countries that have different levels of corruption. A comparative case study design was chosen, looking into the fisheries sector in Iceland and the forestry sector in Romania. We conducted 25 semi-structured interviews with various stakeholders sampled through a snowball method. Qualitative coding and systems analysis were used to analyse the interviews. The results indicate that comprehensive and ambitious legislation does not necessarily translate into successful resource governance systems. In general, the institutions that were put in place to enforce and monitor the legal codes and regulations did not have the capacity to carry out their role. Additionally, interviewees were generally found to have a widespread perception of there being a corrupt relationship between politics and big companies operating in their sectors. Our findings suggest that when people hold such perceptions, it undermines anti-corruption policy efforts in the resource sectors, which can then impede sustainable resource management.
\end{abstract}

\section{Keywords}

anti-corruption; corruption; enforcement mechanisms; governance; monitoring; natural resources; renewable resources

Issue

This article is part of the issue "Fighting Corruption in the Developed World: Dimensions, Patterns, Remedies" edited by Fabrizio Di Mascio (University of Turin, Italy) and Simona Piattoni (University of Trento, Italy).

(C) 2020 by the authors; licensee Cogitatio (Lisbon, Portugal). This article is licensed under a Creative Commons Attribution 4.0 International License (CC BY).

\section{Introduction}

Environmental issues are higher on the public agenda in light of growing awareness of climate change and therefore further efforts are needed to understand how resources can be used sustainably. The tragedy of the commons has been widely cited as a metaphor to portray the overuse of a renewable resource such as fisheries and forests (Ostrom, 1999). Rules and systems have therefore been established to regulate use or extraction, but corruption can impede the achievement of management goals. Resource management systems are vulnerable to different forms of corruption at all stages of the value chain, but understanding the roles and influences of actors in such systems provides important insights into how to address the risks (Kolstad, Søreide, \& Williams, 2008). We adhere to the interpretation of corruption used by Sumaila, Jacquet, and Witter (2017, p. 93) in this context, where they describe it as "acts of 'cheating,' whereby individuals or larger entities act in an illegal manner" which serves to undermine both the resource itself as well as its management. Heywood (2016) suggests that one of the reasons measures to reduce corruption have not been effective, is that disaggregation of the different types of the phenomenon, actors involved and sectoral context has been insufficiently addressed. 
Mapping out the corruption risks in the governance of renewable natural resources, such as fisheries and forestry, as well as exploring the policies aimed to reduce them, is both relevant and important in the current global sustainability context. Such work should not solely be directed towards developing countries, especially since according to the Group of States Against Corruption (GRECO, 2017, p. 20), "weaker democracies look to Europe for guidance in their fight against corruption." Therefore, a comparative qualitative case study design was chosen to shed light on the research question of 'What generates corruption risks in the value chain of renewable resources in Europe, and how has it been addressed?' We aim to improve the understanding of responses to potential risks and how they play out in countries with different levels of corruption. Improving understanding of both the risks and the policies meant to tackle them provide insights into the barriers to sustainable resource management. The small sample that was subject to this study limits the generalization of the findings, which could be strengthened if applied to further cases.

\section{Methods and Research Material}

We limit the scope of the research by opting for a caseoriented investigation (Ragin, 1987) and thus explore the phenomenon within a real-life context by employing an exploratory case study strategy (Robson, 1993; Yin, 2014). Empirical analysis was undertaken as a binary comparison between two selected cases, Iceland and Romania (Tarrow, 2010). The aim is for the understanding and knowledge generated from the cases to shed light on the phenomenon in general, making this an instrumental inquiry (Stake, 1995).

The rationale behind the case study selection was to explore the initial assumption that countries recorded as having low corruption levels were more successful in addressing corruption risks in their value chains as opposed to those recorded as having high corruption levels. According to the Corruption Perceptions Index, the lower a country is ranked on the list, the greater the perception that corruption is prevalent. Romania has historically been ranked amongst the bottom of the European countries while Iceland has been amongst the top. In 2019, Romania was ranked 70th and Iceland 11th out of 180 countries on the list (Transparency International, 2019). The cases were considered feasible as the researchers already had background knowledge and connections in the countries which served to ensure both accessibility to participants as well as limiting the resources needed to carry out the fieldwork.

As the focus of the study was to explore responses to corruption risks in natural resource management in general, as well as how they played out in different sectors, a decision was taken not to look at the same resource for both countries. Although they have different resource bases, forestry in Romania and fisheries in Iceland have both played an important role for each country in terms of social and economic development (Ioras \& Abrudan, 2006; Kokorsch \& Benediktsson, 2018). The de facto privatization of the Icelandic fisheries and the repossession of forests in Romania following the collapse of the communist regime, both occurring in the 1990s, has meant the sectors have been faced with a variety of challenges. Even though the sectors are different, they share commonalities in that external governmental agencies are legally responsible for enforcement of the law. The research question could, therefore, be explored by comparing these two cases.

An application for the research was approved in 2017 by the Research Ethics Committee of the University of Iceland. Following that, a stakeholder map was developed for each case study (Reed et al., 2009; Durham, Baker, Smith, Moore, \& Morgan, 2014), and key informants recruited as a result. They were asked to provide a list of possible participants for the research, according to a snowball sampling method (Robson, 1993), to ensure anonymity. In-depth semi-structured interviews took place from March to October 2018. As seen in Table 1, 25 interviews were conducted; 12 in Iceland and 13 in Romania. The interviews were conducted in Icelandic, English, and Romanian, with a translator present in Romania; they lasted approximately an hour, with a few exceptions ranging from 40 minutes to 2,5 hours. To ensure a representative sample, 12 of the interviews were taken in the capitals, while 13 were conducted in rural areas or smaller cities.

As can be seen in Table 1, the number of participants exceeds the number of interviews in the Romanian case. That is because a participant showed up to the interview with colleagues. When the numbers in the stakeholder groups are added up, they are larger than the number of participants since it was common that people had served multiple roles in the sector and could, therefore, be categorized in more than one group. Notice that we also refer to 'current/former' role in order to better ensure anonymity. In terms of the age of the participants, each age group is represented. There is, however, an imbalance between female and male participants. We failed to recruit a current/former member of government as well as high-level representative from large companies operating within the sectors. The sample is considered large enough to gain a general understanding of the phenomenon under study, even though limitations in the stakeholder sample are present, especially in terms of gender diversity.

The qualitative coding procedure used to analyse the interviews was adapted from the work of Turner, Kim, and Andersen (2013). Causal loop diagrams were generated based on mechanisms described by the interviewees. This method allows us to compare and contrast the dynamics that contribute to the corruption risks in both cases and is further described below. 
Table 1. Overview of the interviewees by stakeholder categorization, country, gender, and age.

\begin{tabular}{|c|c|c|}
\hline Stakeholder & Iceland & Romania \\
\hline NGO staff & 0 & 4 \\
\hline Current/former resource owner/recipient & 2 & 2 \\
\hline Current/former Member of Parliament & 2 & 1 \\
\hline Current/former journalist & 1 & 1 \\
\hline Current/former parliamentary staff & 1 & 1 \\
\hline Academia & 3 & 3 \\
\hline Current/former public official & 4 & 3 \\
\hline Current/former member of government & 0 & 0 \\
\hline Resource owner associations/organization & 2 & 1 \\
\hline Harvesting operations/exploitation of resource & 5 & 4 \\
\hline Small business owner & 1 & 1 \\
\hline Big industry worker & 2 & 1 \\
\hline Owner or manager of a big corporation & 0 & 0 \\
\hline Current/former local politician & 1 & 0 \\
\hline Finance sector & 1 & 0 \\
\hline Total Interviews & 12 & 13 \\
\hline Total Participants & 12 & 15 \\
\hline \multicolumn{3}{|l|}{ Of those: } \\
\hline Number of female participants & 3 & 1 \\
\hline Number of male participants & 9 & 14 \\
\hline Age $20-40$ years & 2 & 5 \\
\hline Age $40-60$ years & 5 & 6 \\
\hline Age $60-80$ years & 5 & 4 \\
\hline
\end{tabular}

\section{Theoretical Background}

The academic debate on corruption has revolved around whether to view it as a collective action problem or a principal-agent problem, but recent theoretical work has suggested the two approaches could be considered as complementary (Marquette \& Peiffer, 2019; Williams \& Le Billon, 2017). Persson, Rothstein, and Teorell (2018) state that collective action theory could be complementary to principal-agent theory in cases where corruption is not systemic and the problem of collective action has been solved. The principal-agent approach then ensures formal mechanisms of control, where corruption is detected and those engaging in it are punished. The approach includes the utility maximization concept of corruption, which suggests that it results from rational behaviour in which individuals participate in corruption because the benefits outweigh the costs (Rose-Ackerman, 1978; Søreide, 2014). The expected benefits might consist of monetary gains, power, and status, whereas the costs can include bribe payments to hide the act, efforts to hide the crime, moral costs of violating societal rules and norms, and the perceived risk of getting caught (Søreide, 2014). Collective action theory dictates that following this logic of perceived cost and benefit, individuals will base their decision, on whether to engage in corruption or not, on the perception of how likely it is that other individuals are corrupt (Persson et al., 2018).

The pillars of an anti-corruption policy are increasing transparency, strengthening enforcement, the pres- ence of an anti-corruption agency, higher wages for public officials, and efforts to change societal norms (Fishman \& Golden, 2017). These can also be categorized as policies aiming at monitoring and incentive programs or those which intend to alter the rules of the system, the latter category being less explored (Hanna, Bishop, Nadel, Scheffler, \& Durlacher, 2011). In line with the utility-maximizing concept, successful corruptionreduction strategies deter individuals from engaging in corruption by making the cost outweigh the benefits (Hanna et al., 2011).

According to Kolstad et al. (2008), corruption can occur more frequently within resource management where the capacity to enforce and monitor the sectors is low. Additionally, the EU's anti-corruption report (European Commission, 2014) states that anti-corruption rules lack enforcement since the relevant institutions have insufficient capacity and inadequate political will to tackle it. The policies hinge upon political incentives and approval as they can be undermined by a lack of political will. Policy success in this area can be achieved when authorities responsible for enforcement are supported by highlevel political officials (Fishman \& Golden, 2017).

\section{Results}

The empirical analysis of the interview data suggests that the implementation and enforcement of legal frameworks are vital factors when it comes to perceptions regarding corruption in the resource sectors. We found 
that in both cases, institutions tasked with monitoring and enforcing legislation were not provided with the capacity to carry out their role. This resulted in the perception of there being a suspicious relationship between politics and the businesses operating in the sectors.

\subsection{Iceland's Institutional Organization}

The fisheries sector in Iceland has a positive international image when it comes to the governance of natural resources, as it is reputed for its sustainable fisheries management. However, even though the fishing quota system is renowned for its efficiency, it is still the source of a great deal of social and political debate in the country (Chambers \& Carothers, 2017; Kokorsch \& Benediktsson, 2018). Icelandic fisheries management is mainly based on two bodies of legislation which aim to improve management of marine resources to ensure that they will be used sustainably, guaranteeing maximum long-term output for the Icelandic nation (Icelandic Government, 1996, 2006). The laws stipulate that the public authorities responsible for monitoring the fisheries sector are the Directorate of Fisheries (DoF), which operates under the Ministry of Industries, Tourism and Innovation. The Icelandic Coast Guard protects the $\mathbf{2 0 0}$ marine-mile zone around Iceland from intruders and occasionally accompanies the DoF to monitor whether vessels operating out at sea are doing so according to their permits.

\subsubsection{The DoF}

The role of the DoF is laid out in The DoF Act (Icelandic Government, 1992). It is in charge of enforcing the Fisheries Management Acts, as well as administering and monitoring fishing activities. A part of its role is to accompany fishermen on their fishing trips and to monitor operations and observe whether the discarding of catch is taking place. DoF also measures the size of fish that are caught and send the data to the Marine and Freshwater Research Institute, which then compares the sizes to those of fish that are landed to see whether there is any discrepancy which would indicate that so-called 'high-grading' is taking place, meaning that fishermen discard the smaller fish out at sea and only bring the bigger, more valuable ones to shore. During 2017, employees of DoF went on 306 such trips (The Icelandic DoF, 2017). As demonstrated in the interviews, each small boat is surveyed 1-2 times per year while each large vessel is surveyed bi-annually. 25 individuals within the DoF perform these inspections (The Icelandic National Audit Office [INAO], 2018).

\subsection{Legislation Lacking Enforcement Mechanisms}

A system introducing quotas into the fisheries sector in Iceland was introduced in 1984, in an effort to reverse the trend of excessive overfishing (Danielsson, 1997). The legislation on fisheries management has been amended ever since, and the changes scrutinized. In a report by INAO (2018) on the DoF, it is clear that there are several limitations to DoF operations. It states that monitoring of the fisheries sector is extensive and difficult to carry out. Furthermore, surveillance of the fish catch being weighed was deemed unsatisfactory, meaning that there were opportunities for an individual or a company to report lower catches than they actually landed, indicating that more fish could have been caught than ended up being reported. Additionally, the report claimed that monitoring of catch discard was both weak and unsystematic.

A majority of the Icelandic interviewees voiced concerns over the lack of enforcement mechanisms available to the monitoring authorities. According to a current/former staff member of the DoF, employees agreed that the institution was not powerful:

You know the regulation...or the legal framework is so weak. We can't handle to, you know, close cases. There is always something, and I even know of cases where those that know someone in the Ministry [of Fisheries], can just place a call to the Ministry and get cases dismissed. (personal communication)

The individual further described that DoF monitoring staff regularly encountered scepticism from small-boat fishermen, since they believed the authorities focused on smaller players with minor offences, rather than the bigger vessels. Furthermore, when discussing enforcement, a current/former academic stated:

And you need ways to actually say that, you know, these are the rules, these are the people that are responsible for the rules, and then when the rules are broken, this is what happens. I think, that is where I think, in these later parts, where the system sort of breaks down. (personal communication)

Actors have begun to expect that there will be no consequences brought down upon those who cheat the system. A current/former journalist claimed that those working in the sector actually wanted the rules to be clearer because the alternative to clear rules was chaos. If the monitoring system was so easy to manipulate and expected consequences for doing so were limited, people who did follow the rules went through the following thinking process: "This is a system that is easy to cheat somehow. And then...then I, who am following the rules, start to think: Why bother? Why don't I just do this too? Nobody does anything about it" (personal communication). In theory, law stipulating financial sanctions against those catching fish above their legal limit provides the DoF with all kinds of power to act. In reality, they lack the capacity to bring cases forward. By applying system analysis we illustrate linkages between the lack of enforcement and the risk of corruption, as identified in our interviews (Figure 1). 


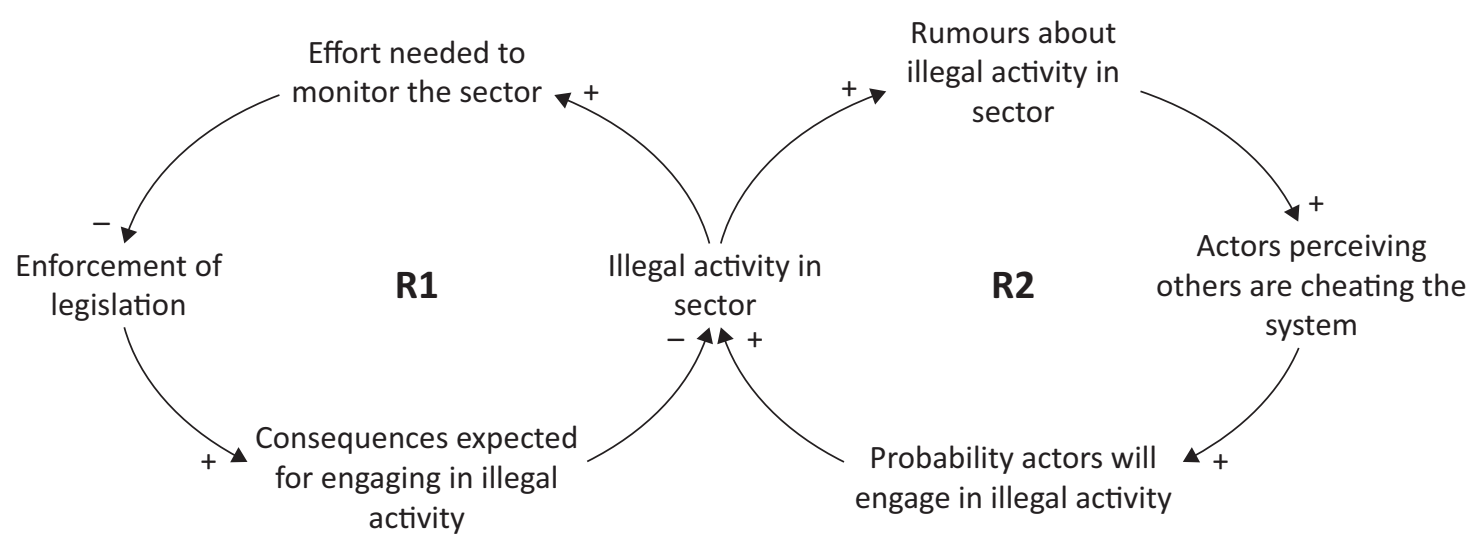

Figure 1. A causal loop diagram representing the two reinforcing vicious cycles that drive illegal activity in the sector.

A causal loop diagram contains either reinforcing $(R)$ or balancing (B) loops. The arrow denotes the nature of the interaction between two variables. If an arrow has a plus sign, it means that an increase in the first variable will lead to an increase for the second variable, or a decrease will lead to a decrease. If it has a minus sign, the change occurs in the opposite direction, an increase will lead to a decrease or vice versa. When the loop contains only plus signs, or the minus signs add up to an even number, the loop is reinforcing; if not, it is balancing (Sterman, 2000).

Two main reinforcing feedback loops increase the risk of corruption in Figure 1, labelled R1 and R2. The loops amplify behaviour, and in this case, the system is trapped in a vicious cycle. Especially if no balancing loops are present to counteract the behaviour, for example through anti-corruption measures aimed at increasing the perceived consequences of engaging in illegal activity. When illegal activity takes place, more effort is needed to monitor the sector. It takes less time and resources to verify that individuals are working according to the law, when they indeed are, than when they engage in illegal activity. When more effort is needed to monitor the sector, enforcement of legislation decreases. When enforcement decreases, individuals expect fewer consequences for engaging in illegal activity, which in return increases illegal activity in the sector. As illegal activity increases, more rumours spread about such illegal activity within the small community of fishermen. Those rumours increase individual's perceptions that others are cheating the system, which will raise the probability of them engaging in illegal activity as well. As highlighted above, this 'why bother' mentality raises the probability of illegal activity taking place, since the perceived benefits might outweigh the costs, especially when accompanied by low expectation of consequences.

\subsection{Romania's Institutional Organization}

Romania is known for its extensive forests and is one of the main timber producers in Europe. However, alarming rates of illegal deforestation (Ministry of Environment, Water, and Forest, 2019) have had a considerable impact on the country's ability to ensure sustainable forestry management (Bouriaud \& Marzano, 2016). The legislative act on the forestry resource in Romania is the Forest Code which aims to regulate the sustainable management of the forestry resources and provide forest resources for the current and future needs of society (Romanian Government, 2008). All forest is divided into units, that are either privately or publicly owned. Each forest unit needs to be administered by a forest district. The National Forestry Administration, Romsilva, has historically been in charge of the forest districts and operates under the Ministry of Environment, Water, and Forests (Romanian Government, 2009). Forest guards are in charge of monitoring the forests.

\subsubsection{Forest Administration}

Romsilva, a state-owned enterprise, operates on the basis that it is financially autonomous (National Forestry Authority Act, 2009). It has a dual role, but it is tasked with maximizing profits generated from forestry exploitation, while at the same time being in charge of sustainably administering all publicly owned and national forests in Romania (Rosilva.ro, 2019; Volintiru, Trandafir, Toma, Nutu, \& Damian, 2017). After changes were made to the Forest Code in 2008, all forest owners, public and private, were obliged to ensure that their forests were managed according to the law (Niță, 2015). In order to abide by that law, they needed to purchase forest administration services from either Romsilva or a private forest administration service. Those services include a forest management plan, usually valid for 10 years. Among other issues, the plan specifies the harvesting volume that is permitted and which tree species should be grown (Bouriaud \& Marzano, 2016). The Romanian public currently holds a poor perception of forest administration since Romsilva has been affected by corruption scandals, resulting in a negative portrayal of their activities in the media (Palaghianu \& Dutca, 2017; Volintiru et al., 2017). 


\subsubsection{Forest Guards}

The Forest guards are considered to be public officials as they operate directly under the Ministry of Environment, Water, and Forests. The country is separated into nine different territories, with each territory having a head forest guard in charge of the monitoring operations. Romania is divided into 42 counties, so one forest guard territory includes several counties. In total, there are approximately 600 forest guards employed, in charge of monitoring a forest area encompassing 6,5 million hectares (Institutul National de Statistica, 2018). The role of the forest guards was described in an interview with a current/former individual working in private forest administration as "everything" (personal communication). They are responsible for monitoring the entire harvesting phase, from verifying that management plans are done according to the law to how the timber is transported on public roads. The individual further stated:

The payment method is problematic because you cannot survive with a salary of a forest guard [approx. $400 \mathrm{EUR} / \mathrm{month}$ ]. You cannot have that salary when you guard a land that is so large and expensive. You are responsible all year and all hours with this kind of salary. The legislation is made like this in order for politicians to have a certain amount of political capital in elections. The forest guard is responsible for everything that gets stolen from the forest while he has 1000 hectares to monitor. (personal communication)

Numerous interviewees voiced concerns over the capacity of the forest guards to perform their role. According to interviewees, salaries of forest guards used to be even smaller and were raised in an effort to combat illegal logging. The rationale was that if forest guards had higher salaries, there would be less incentive for them to engage in corruption and criminal activity. Additionally, a measure was introduced, so that if timber disappeared from the forest and the perpetrators not found, the forest guards would be held personally responsible for the missing timber and have to pay a fine equal to the market value of that timber. Interviewees also raised the issue that forest guards were vulnerable when going into the field to monitor the forests and should, therefore, carry a weapon. Indeed, as analysis of the data was ongoing in 2019, two forest guards in Romania were murdered whilst carrying out their duties (McGrath, 2019). As a result, working as a forest guard can be viewed as a high-risk occupation, and the lower chamber in the Romanian parliament recently approved legislation obliging forest guards to carry a weapon on duty (“Decizie după crima," 2019).

\subsection{Legislation Lacking Legitimacy and Enforcement}

The forestry sector faced substantial challenges following the collapse of the communist regime in the country in 1989. A sector that had been state-owned needed to be repossessed and given back to its former owners and undergo extensive structural change (Palaghianu \& Dutca, 2017). In terms of the development of the forestry legislation, it became apparent that the changes made in 1996 resulted in a decrease in forest area due to the lack of penal consequences for those who violated the law (Niță, 2015). Even though legislation has since been amended, the country is still struggling to combat illegal activity in the sector. A majority of the Romanian interviewees brought up legislation in the forestry sector during the interviews. Concerns were raised over how prescriptive and complicated the legislation was, which made it difficult to understand and enforce. A current/former Romsilva employee stated:

Romania used to have, before the change from the communist regime, one of the best administrative forest management systems in Europe. Very prescriptive, very nice. We have very nice forests due to them. But this system is no longer adapted to the nature of the ownership nowadays. So, you cannot enforce it. You will have a level, a high level of illegalities. Because standards of the law are rather high up. (personal communication)

Additional interviewees expressed that in their view, the laws were outdated and unfair. The technical standard specified in the legislation, as well as rules on species composition and sampling density, were perceived as being outdated and imposed, as they needed to be brought up to date with the modern era. An individual with extensive experience in the forestry sector explained that the legal code "is not proper for our time" (personal communication) when discussing the technical standard in the legislation, because forests were growing much faster now due to a warming climate. Moreover, an interviewee currently/formerly employed in the private forest administration expressed the view that "our legislation now starts from the idea that people steal and are corrupt" (personal communication), which made the legislation too prescriptive. The individual believed that the legislation could be simpler if it emphasized the benefits people could get from the sector, rather than solely laying out how people could be deterred from stealing from the forest. Furthermore, forest owners were not satisfied with being obliged to buy forest administration services and the prescriptive legislation did not allow them the freedom to make management decisions about their own forest. They wanted to be free to set their own goals for their forest, which aligns with what Palaghianu and Dutca (2017) found in their work. In Figure 2, we showcase the linkages between the lack of enforcement and the risk of corruption.

As can be seen in Figure 2 loop R1, when there is less enforcement of the legislation, people expect fewer consequences for engaging in illegal activity. The fewer consequences they expect, the more illegal activity will take place in the sector, which means that more effort 


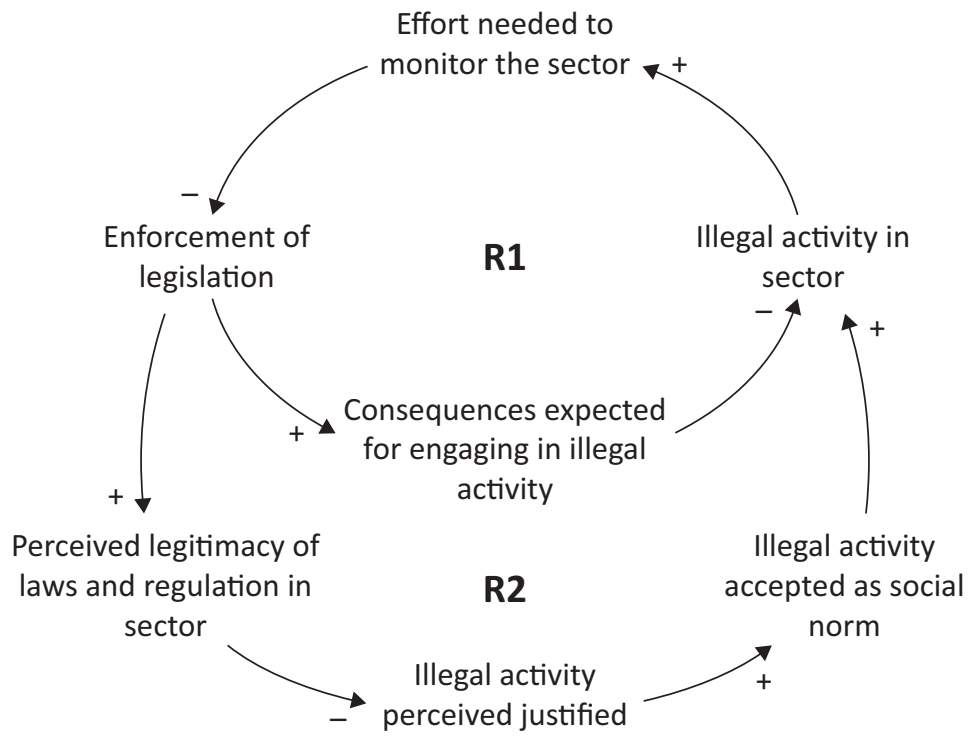

Figure 2. A causal loop diagram representing the two reinforcing loops that undermine enforcement of the forestry legislation.

is needed to monitor it, which again decreases enforcement. Loop R2 demonstrates that when enforcement decreases, the perceived legitimacy of laws and regulation in the sector decreases, which increases the perception that illegal activity is justifiable. When illegal activity is increasingly seen as justified, it increases acceptance of illegal activity as being socially normal, which again increases the illegal activity in the sector. When illegal activity increases, so does the effort needed to monitor it. Once more effort is needed for monitoring, the capacity to enforce the legislation goes down which translates into less enforcement.

Even though there seems to be awareness amongst stakeholders that monitoring of the sector is ineffective due to low capacity of public officials, recent measures such as increasing the wages of forest guards does not appear to have resulted in improvements in enforcement, as indicated by data on illegal logging (Ministry of Environment, Water, and Forest, 2019).

\subsection{Perceptions of Suspicious Relationships}

In both the Iceland and Romania cases, interviewees held perceptions that economically powerful actors in the sectors had the ability to use their financial power to influence the political sphere. Monitoring authorities were weak due to the fact that the line between business and politics was thin. As described by a current/former member of the Icelandic parliament:

It has...given up on being a monitoring system. Like it should be. And instead operates within the boundaries that the interest groups decide. Set them, you know. Of course, they observe and intervene, but, but...certain things they leave out. And they know, that if they go to [name of a big company] and un- cover wrong weighing [of fish] that then they are just up against someone that is out of their reach. Because fishing company owners are so powerful, they bypass monitoring authorities. Bypass the DoF and just go to the Ministry. Into the political parties. (personal communication)

A similar view was held by a current/former public official who stated that "the big fishing quota owners control what goes into the legislation" (personal communication). A former/current academic further stated: "In my opinion interest groups have too much influence and politicians are their puppets" (personal communication). Similar perceptions were found in Romania, as can be seen in this comment from a current/former journalist:

Regarding the partnership between the industry and Romsilva for example, and the Romanian state. I'll put it this way: Because in so many cases the corrupt politicians use corrupt businessmen, for their profit or financial profit. Or from the political perspective, in so many cases, the election campaigns, every four years, they were funded with illegal money coming from illegal logging. (personal communication)

A current/former forest owner further explained in an interview "Because every government sees Romsilva as a... cow with milk." It appears that managing the stateowned enterprise has been seen by many as an opportunity to obtain wealth, since many former directors with strong political ties to the country's ruling party, Partidul Social Democrat (PSD), have been implicated in corruption scandals (Volintiru et al., 2017). Furthermore, during an interview with an individual with extensive experience having served multiple roles in the sector, the individual stated: 
And nobody wants to go to...in the forest to cut, to make some services and contracts with Romsilva. Because everybody knows what's going on. They have some problems. But...why? Because the political management, the political management are allowing illegal cutting. Illegal volumes. Illegal money. They are actually looking for illegal money. That's the problem. (personal communication)

Effective resource management is dependent on rules to be regarded as legitimate and fair by those operating in the sector. When perceptions of suspicious relationships between businesses and politicians are prevalent, it increases the risk of corruption in the value chain as it undermines anti-corruption efforts. It is therefore important that such actions are directed towards fostering collective action, and not solely designed through a principal-agent approach (Mungiu-Pippidi, 2013).

\subsection{Corruption Risks in the Value Chains}

An overview of the corruption risks identified by respondents is demonstrated in Table 2. There we take the resource value chain from legislation to harvesting, monitoring and revenue management, and point to which corruption risks were identified by interviewees at each step.

In both cases, we see similarities in the corruption risks throughout the value chains, even though the sectors in question are different due to the nature of the resource. However, Iceland and Romania have tackled these risks in different ways.

\subsection{Anti-Corruption Policies}

Both countries are subject to having their anti-corruption efforts evaluated by GRECO. The main issues in Iceland relate to conflicts of interests, as the management of public affairs is excessively intermingled with private interests. Lobbyism by third parties to influence government work and revolving doors go unregulated (GRECO, 2018a). Romania's progress towards combat- ting corruption is closely monitored by the EU (European Commission, 2019). Issues and occasions where parliamentarians, judges, and prosecutors have misused their power and functions for personal gain come up regularly and prosecutions of such actions have been ineffective (GRECO, 2018b). Regarding illegal logging specifically, the European Commission sent the country a letter of formal notice urging action in February of 2020 (European Commission, 2020).

\subsubsection{Iceland's Efforts to Increase Transparency}

The policies Iceland has adopted in order to address corruption risks within the fisheries sector have mainly been based on monitoring and incentives procedures through increased transparency. However, according to Bauhr and Grimes (2017), accountability is not necessarily increased by transparency, as access to information does not guarantee answerability and sanctioning, and more research is needed to understand the conditions under which increasing transparency will reduce corruption risks.

According to Suuronen and Gilman (2019), at-sea observer programs are the most effective monitoring schemes available today, but with recent technological advances, remote electronic monitoring has become increasingly feasible. Remote electronic monitoring does have limitations, but complimenting it with human observers could increase transparency in fisheries management (Ewell, Hocevar, Mitchell, Snowden, \& Jacquet, 2020). Interviewees expressed satisfaction with the GPS tracking system, whereas according to a current/former academic:

Any activities out at sea, so if they are illegally fishing somewhere, that is actually really well known because they have GPS. And if they are getting close to an area they shouldn't be fishing, there is real-time monitoring of that. (personal communication)

Transparency in fish pricing and catch numbers was brought up in interviews, as those numbers were eas-

Table 2. Corruption risks identified within the sectors.

\begin{tabular}{lll}
\hline Romania & Resource value chain & Iceland \\
\hline $\begin{array}{l}\text { Legislation too complicated and outdated } \\
\begin{array}{l}\text { Underestimations in forest management } \\
\text { plans }\end{array}\end{array}$ & $\begin{array}{l}\text { Legislation/regulations } \\
\text { Harvesting operations }\end{array}$ & $\begin{array}{l}\text { Legislation lacking enforcement mechanisms } \\
\text { Underestimations of fish weight }\end{array}$ \\
$\begin{array}{l}\text { Illegal logging } \\
\begin{array}{l}\text { Forest guards do not have capacity to } \\
\text { monitor the area they are assigned }\end{array}\end{array}$ & Monitoring of operations \\
$\begin{array}{l}\text { Revenues generated in sector used to gain } \\
\text { political influence }\end{array}$ & Revenue management & $\begin{array}{l}\text { DoF does not have capacity to perform } \\
\text { their legal duties }\end{array}$ \\
\hline
\end{tabular}

Source: The analytic framework is adapted from Alba (2009). 
ily accessible online. However, concerns also harmonized with observations from the INAO (2018) report, that even though catch numbers were available, the identified corruption risks related to the weighing of catch and discard levels put those numbers under scrutiny. A current/former public official, for example, stated that "nobody knows how much of the resource is being exploited" (personal communication). The INAO (2018) recommended that the sector should take up electronic monitoring by installing cameras on board as well as introduce whistleblowing protection measures for fishermen coming forward with accusations of discarding. Those measures aim to reduce corruption risks in the harvesting operations and monitoring parts of the value chain.

\subsubsection{Romania's Application Inspectorul Padurii (Forest Inspector)}

According to Meehan and Tacconi (2017), the most compelling reduction in deforestation is brought about by efforts to reduce the risk of corruption throughout all stages of forest management. Anti-corruption resolutions through rule-changing interventions are less common than those focusing on incentives and monitoring programmes and include the use of technology to bypass bureaucratic procedures, as in the Romanian case (Hanna et al., 2011). Once asked about what had been done to increase trust in the sector, most interviewees mentioned an application set up by the government which ordinary citizens could download to their mobile phones. Using the application, they could take pictures of licence plates of trucks carrying logs, which could inform them whether that truck was authorized to be driving on that particular road at that time. A current/former academic stated:

Of course when you are more open and...you are, you show what you are doing you get more trust. For example, the authorities doing this system that everybody can check the illegal logging, you know, you get more trust of this... of this ministry or politicians and so on. (personal communication)

It was seen as a good public policy instrument that the general public could use to report on suspected illegal activity. However, amongst the interviewees, there seemed to be confusion whether the application had been discontinued or not. An individual currently/formerly working for an NGO in Romania stated: "I just know that people were angry that they had this opportunity to actually send official information to the authorities and then it was just, it was just scrapped" (personal communication). The same individual expressed fears that the level of reporting of illegal logging was down "because if people see that the state doesn't even want to know, then why should you report it?" (personal communication). A majority of interviewees were under the impression that the app had been discontinued for political reasons. However, according to a media interview with the CEO of the IT company that developed the app, it is still functional, but it needed improvements and updates which the company developed and made ready for release in 2017. The PSD government, however, blocked the update (Savaliuc, 2020).

\section{Discussion}

In both of the cases in question, comprehensive legislation regarding resource management had been put in place. However, a lack of enforcement meant that the monitoring authorities were perceived of as weak and illegal activity was believed to go largely unpunished. When monitoring authorities in both countries failed to comply with their role due to lack of capacity or resources, those operating in the sector become aware, which influences how anti-corruption policy measures play out. The resource governance systems can become stuck in a vicious cycle, as described and discussed for both fisheries in Iceland and forestry in Romania. Less capacity to enforce legislation leads to the perception that the consequences of illegal activity are minor, which can further amplify illegal activity in the sectors. Additionally, results indicate that more resources are being taken than reported through underestimations in forest management plans and under-reporting of fish weights. In such instances, the countries are missing out on royalties and tax revenues.

The underlying assumption going into the case studies was that less corrupt countries were better able to address corruption risks in their resource value chains. Similar risks were identified in both resource sectors but the countries have opted for different anti-corruption mechanisms to limit them. Even though Romania does have more serious challenges when it comes to fighting corruption, it was unexpected to find that in both cases, anti-corruption measures were being undermined by the perceptions of there being suspicious relationships between public power and private interests. This highlights that international indexes ranking countries' perceived corruption levels, such as the Corruption Perceptions Index, are not well suited to inform policymakers on the need for anti-corruption measures in specific sectors or contexts.

These findings suggest that when there is a prevalent perception that governments have allowed monitoring institutions to become weak, due to lack of political will, it increases corruption risk in the resource sector, which impedes sustainable management of natural resources. Addressing these risks through a framework that sees the collective action approach and the principal-agent approach as complementary would be beneficial since elements of both have been identified in this context. Furthermore, results from this study indicate that when anti-corruption policies are not accompanied by sufficient enforcement and political will, the 
probability of their success is reduced, which agrees with the findings of a recent report on corruption within the fisheries sector by the United Nations Office on Drugs and Crime (2019).

Vulnerabilities in Iceland due to conflicts of interests and instances of misuse of power for personal gain in Romania, as brought up by GRECO, appear to have wider relevance. The implications being that weaknesses in national anti-corruption policies can translate into inadequate corruption reduction measures in specific sectors, which this study has shown is the case in countries with both high and low levels of corruption. Questions that arose during the research process related to how sufficient political will could be generated for strengthening national anti-corruption policies, and how governments could convince the public of their merits as well as their policies, given that perceptions are not easily changed. Based on this work, we recommend that policy measures should aim to build the institutional capacity needed to enforce the comprehensive legal frameworks already in place, which would show the public that there really was a political will to tackle such issues.

\section{Conclusion}

In this study, we demonstrate mechanisms by which corruption risks are generated throughout resource value chains. Vicious cycles were identified in both cases, where less capacity to enforce the legislation leads to the perception that the consequences of illegal activity were minor. That further amplified illegal activity in the sectors, resulting in more effort being needed for monitoring, and subsequently, less capacity of authorities to enforce the legislation. A widespread perception was also found among interviewees of there being a suspicious relationship between politics and big companies licensed by the authorities to harvest and process natural resources. That perception seemed to be shaped by the inability of monitoring authorities to carry out their role. The processes we have described weaken anticorruption efforts in the sectors and impede sustainable resource management since it can lead to more of the resources being exploited than officially reported. Even though our results point to mechanisms that increase the risk of corruption by undermining enforcement of legislation, we propose that our findings could be strengthened if the analysis were applied to further cases.

\section{Acknowledgments}

This research was funded by the European Union's Horizon 2020 research and innovation programme under the Marie Skłodowska-Curie Innovative Training Network grant agreement No. 675153 (AdaptEconlI). We would like to extend gratitude to the interviewees, as well as Antonia Cioanca and Claudiu Eduard Nedelciu for help with translations.

\section{Conflict of Interests}

The authors declare no conflict of interests.

\section{References}

Alba, E. M. (2009). Extractive industries value chain: A comprehensive integrated approach to developing extractive industries (Extractive Industries and Development Series No. 3 and Africa Working Paper Series No. 125). Washington, DC: The World Bank. Retrieved from http://documents.worldbank. org/curated/en/282401468339611763/pdf/484240 NWP0Box31ei1for1development13.pdf

Bauhr, M., \& Grimes, M. (2017). Transparency to curb corruption? Concepts, measures and empirical merit. Crime, Law and Social Change, 68(4), 431-458. https://doi.org/10.1007/s10611-017-9695-1

Bouriaud, L., \& Marzano, M. (2016). Conservation, extraction and corruption: Is sustainable forest management possible in Romania. In E. Gilberthorpe \& G. Hilson (Eds.), Natural resource extraction and Indigenous livelihoods: Development challenges in an era of globalization (pp. 221-240). London: Routledge.

Chambers, C., \& Carothers, C. (2017). Thirty years after privatization: A survey of Icelandic small-boat fishermen. Marine Policy, 80, 69-80. https://doi.org/ https://doi.org/10.1016/j.marpol.2016.02.026

Danielsson, A. (1997). Fisheries management in Iceland. Ocean and Coastal Management, 35(2/3), 121-135.

Decizie după crima din Maramureș! Pădurarii vor primi arme pentru a se putea apăra [Decision after the crime in Maramureș! The foresters will receive weapons to defend themselves]. (2019, October 30). Antena3.Ro. Retrieved from https://www.antena3. ro/actualitate/padurarii-vor-primi-arme-pentru-ase-putea-apara-543535.html

Durham, E., Baker, H., Smith, M., Moore, E., \& Morgan, V. (2014). The BiodivERsA Stakeholder Engagement Handbook. BiodivERsA: Paris. Retrieved from https:// www.biodiversa.org/706/download

European Commission. (2014). EU anti-corruption report. Brussels: European Commission.

European Commission. (2019). Commission staff working document: Romania: Technical report accompanying the document Report from the Commission to the European Parliament and the Council on Progress in Romania under the cooperation and verification mechanism. Brussels: European Commission. https://doi.org/10.1017/CBO9781107415324.004

European Commission. (2020). February infringements package: Key decisions. Brussels: European Commission.

Ewell, C., Hocevar, J., Mitchell, E., Snowden, S., \& Jacquet, J. (2020). An evaluation of regional fisheries management organization at-sea compliance monitoring and observer programs. Marine Policy, 115. https:// doi.org/10.1016/j.marpol.2020.103842 
Fishman, R., \& Golden, M. A. (2017). Corruption: What everyone needs to know. New York, NY: Oxford University Press.

Group of States Against Corruption. (2017). Eighteenth general activity report of the Group of States against Corruption (GRECO): Anti-corruption trends, challenges and good practices in Europe \& the United States of America. Strasbourg: Council of Europe.

Group of States Against Corruption. (2018a). Fifth evaluation round: Preventing corruption and promoting integrity in central governments (top executive functions) and law enforcement agencies. Evaluation report: Iceland. Strasbourg: Council of Europe.

Group of States Against Corruption. (2018b). Fourth evaluation round: Corruption prevention in respect of members of parliament, judges and prosecutors. Evaluation report: Romania. Strasbourg: Council of Europe. Retrieved from https://rm.coe.int/ fourth-evaluation-round-corruption-prevention-inrespect-of-members-of/168077e159

Hanna, R., Bishop, S., Nadel, S., Scheffler, G., \& Durlacher, K. (2011). The effectiveness of anti-corruption policy: What has worked, what hasn't, and what we don't know (Technical report No. 1909). London: EPPI-Centre. Retrieved from https://scholar.harvard. edu/files/remahanna/files/dfid_corruption.pdf

Heywood, P. M. (2016). Rethinking corruption: Hocuspocus, locus and focus. Slavonic and East European Review, 95(1), 21-48. https://doi.org/10.5699/ slaveasteurorev2.95.1.0021

Icelandic Government. (1992). Lög um Fiskistofu [The Directorate of Fisheries Act] (36). Reykjavik: Althingi.

Icelandic Government. (1996). Lög um umgengni um nytjastofna sjávar [Fisheries Management Act] (57). Reykjavik: Althingi.

Icelandic Government. (2006). Lög um stjórn fiskveiða [Fisheries Management Act] (116). Reykjavik: Althingi.

Institutul National de Statistica. (2018). Romania in figures. Bucharest: Institutul National de Statistica.

loras, F., \& Abrudan, I. V. (2006). The Romanian forestry sector: Privatisation facts. International Forestry Review, 8(3), 361-367. https://doi.org/10.1505/ifor.8. 3.361

Kokorsch, M., \& Benediktsson, K. (2018). Prosper or perish? The development of Icelandic fishing villages after the privatisation of fishing rights. Maritime Studies, 17(1), 69-83. https://doi.org/10.1007/s40152018-0089-5

Kolstad, I., Søreide, T., \& Williams, A. (2008). Corruption in natural resource management: An introduction. U4 Brief, 2008(2). Retrieved from https://www.cmi.no/publications/2936-corruptionin-natural-resource-management-an

Marquette, H., \& Peiffer, C. (2019). Thinking politically about corruption as problem-solving: A reply to Persson, Rothstein, and Teorell. Governance, 32(4), 811-820. https://doi.org/10.1111/gove.12444
McGrath, S. (2019, October 21). Romania forest murder as battle over logging turns violent. BBC News. Retrieved from https://www.bbc.com/news/worldeurope-50094830

Meehan, F., \& Tacconi, L. (2017). A framework to assess the impacts of corruption on forests and prioritize responses. Land Use Policy, 60, 113-122. https:// doi.org/10.1016/j.landusepol.2016.10.021

Ministry of Environment, Water, and Forest. (2019, November 22). COMUNICAT DE PRESĂ: Ministrul mediului, apelor și pădurilor:"Astăzi, în România se taie, într-un an, aproximativ 38,6 milioane de metri cubi de lemn, cu 20 de milioane peste cifrele oficiale" [PRESS RELEASE: Minister of Environment, Water and Forests: "There are 38,6 million cubic metres of wood being logged annually, which is 20 million more than the official statistics report"] [Press release]. Retrieved from https://bit.ly/2xKfMd2

Mungiu-Pippidi, A. (2013). Controlling corruption through collective action. Journal of Democracy, 24(1), 102-115. https://doi.org/10.1353/jod.2013. 0020

Niță, M. A. (2015). The impact of national and EU legislative framework on the illegal exploitation of forests in Romania: A managerial cause-effect approach. Procedia Economics and Finance, 32(15), 784-789. https://doi.org/10.1016/s2212-5671(15)01462-8

Ostrom, E. (1999). Coping with tragedies of the commons. Annual Review of Political Science, 2(1), 493-535. https://doi.org/10.1146/annurev.polisci.2. 1.493

Palaghianu, C., \& Dutca, I. (2017). Afforestation and reforestation in Romania: History, current practice and future perspectives. Reforesta, 2017(4), 54-68. https:// doi.org/10.21750/refor.4.05.44

Persson, A., Rothstein, B., \& Teorell, J. (2018). Getting the basic nature of systemic corruption right: A reply to Marquette and Peiffer. Governance, 32(4), 799-810. https://doi.org/10.1111/gove.12403

Ragin, C. C. (1987). The comparative method: Moving beyond qualitative and quantitative strategies. Berkeley, CA: University of California Press.

Reed, M. S., Graves, A., Dandy, N., Posthumus, H., Hubacek, K., Morris, J., . . . Stringer, L. C. (2009). Who's in and why? A typology of stakeholder analysis methods for natural resource management. Journal of Environmental Management, 90(5), 1933-1949. https://doi.org/10.1016/j.jenvman.2009.01.001

Robson, C. (1993). Real world research: A resource for social scientists and practitioner-researchers. Oxford: Blackwell Publishers.

Romanian Government. (2008). Codul Silvic [Forest Code] (46). Bucharest: Monitorul Oficial.

Romanian Government. (2009). Regulament de organizare și funcționare a Regiei Naționale a PădurilorRomsilva [National Forestry Authority Act] (29). Bucharest: Monitorul Oficial.

Rose-Ackerman, S. (1978). Corruption: A study in political 
economy. New York, NY: Academic Press.

Rosilva.ro. (2019). Organizare RNP [Organization of Romsilva]. Rosilva.ro. Retrieved from http://www.rosilva. ro/rnp/organizare_p_58.htm

Savaliuc, R. (2020, January 22). Ministerul mediului "sta de 6" la furat de lemne [The Ministry of Environment is "safeguarding" illegal loggers]. Lumea Justitiei. Retrieved from https://bit.ly/2JA0OsF

Søreide, T. (2014). Drivers of corruption: A brief review. Washington, DC: The World Bank. https://doi.org/ http://dx.doi.org/10.1596/978-1-4648-0401-4

Stake, R. E. (1995). The art of case study research. Thousand Oaks, CA: Sage.

Sterman, J. (2000). Business dynamics: Systems thinking and modeling for a complex world. New York, NY: McGraw-Hill Higher Education.

Sumaila, U. R., Jacquet, J., \& Witter, A. (2017). When bad gets worse: corruption and fisheries. In A. Williams \& P. Le Billon (Eds.), Corruption, natural resources and development: From resource curse to political ecology. Cheltenham: Edward Elgar.

Suuronen, P., \& Gilman, E. (2019). Monitoring and managing fisheries discards: New technologies and approaches. Marine Policy. Advance online publication. https://doi.org/10.1016/j.marpol.2019.103554

Tarrow, S. (2010). The strategy of paired comparison: Toward a theory of practice. Comparative Political Studies, 43(2), 230-259. https://doi.org/10.1177/ 0010414009350044

The Icelandic Directorate of Fisheries. (2017). Annual report. Hafnarfjörður: The Icelandic Directorate of Fisheries. Retrieved from http://www.fiskistofa.is/ media/arsskyrslur/Arsskyrsla_2017.pdf

The Icelandic National Audit Office. (2018). Monitoring by the Directorate of Fisheries (Eftirlit Fiskistofu). Reykjavik: The Icelandic National Audit Office.

Transparency International. (2019). Corruption perceptions index. Transparency International. Retrieved from https://www.transparency.org/cpi2019?/ news/feature/cpi-2019

Turner, B. L., Kim, H., \& Andersen, D. F. (2013). Improving coding procedures for purposive text data: Researchable questions for qualitative system dynamics modeling. System Dynamics Review, 29(4), 253-263. https://doi.org/10.1002/sdr

United Nations Office on Drugs and Crime. (2019). Rotten fish: A guide on addressing corruption in the fisheries sector. Vienna: United Nations.

Volintiru, C., Trandafir, G., Toma, B., Nutu, A. O., \& Damian, A. (2017). National report: Romania. Bucharest: Romanian Center for European Policies. Retrieved from https://www.statecapture.eu/ wp-content/uploads/2018/01/RO_c.pdf

Williams, A., \& Le Billon, P. (2017). Introduction. In A. Williams \& P. Le Billon (Eds.), Corruption, natural resources and development: From resource curse to political ecology (pp. 1-14). Cheltenham: Edward Elgar.

Yin, R. K. (2014). Case study research: Design and methods. Thousand Oaks, CA: Sage.

\section{About the Authors}

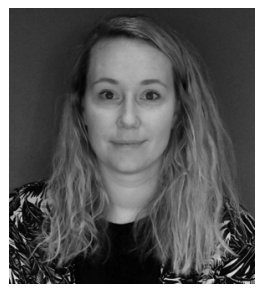

Johanna Gisladottir is a PhD student in the interdisciplinary Environment and Natural Resources program at the Faculties of Political Science as well as Earth Sciences, University of Iceland. In her project, she explores the linkages between corruption, trust, and natural resource governance, using qualitative research methods and systems analysis. She has a BA in Political Science from the University of Iceland and an MPhil in System Dynamics from the University of Bergen, Norway.

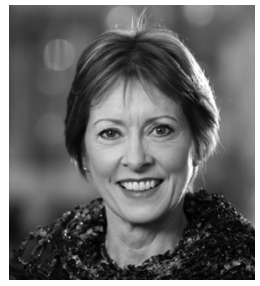

Sigurbjörg Sigurgeirsdottir is an Associate Professor of Public Policy and Governance at the Faculty of Political Science, University of Iceland, where she teaches courses on public administration, public policy, and policy change. She earned her MSc and PhD at the London School of Economics and Political Science in Social Planning. Her current research focuses on health and social care systems, trust and accountability, public policy, and governance.

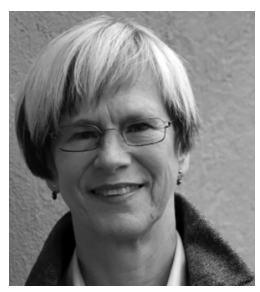

Ingrid Stjernquist is an Associate Professor at the Department of Physical Geography, Stockholm University, Sweden, where she teaches courses on systems analysis, natural resource management, environmental governance, and sustainable forestry. Her professional background is in ecology, energy, and environmental system studies and soil chemistry. Her current research focuses on systems analysis, green infrastructure for ecological sustainability and human well-being, sustainable forestry and bioenergy, and participatory governance in Swedish forestry. 
Kristin Vala Ragnarsdottir is a Professor in Sustainability Science at the Faculty of Earth Sciences, University of Iceland, where she teaches courses on sustainable futures, energy and Earths' resources, and the Earth's critical zone. She earned her MS in Geological Sciences and PhD in Geochemistry from Northwestern University in Evanston, Illinois. Her professional background is in geochemistry, the link between environment and health, and soil eco-social science. Her current research focuses on sustainability solutions for the future including natural resource management, and the wellbeing economy. 